\title{
The Knowledge Base of L2 Pronunciation Teaching: The Case of a Nonnative-Speaking Teacher
}

Joshua Gordon

Recent studies have explored how pronunciation teachers' knowledge, beliefs, and opinions about teaching influence their classroom practices. In addition, recent research has demonstrated the effectiveness of nonnative-speaking (NNS) teachers in pronunciation instruction. However, very little is known about the knowledge base that allows NNS teachers to implement pronunciation instruction. This is an area that requires further inquiry because of the central role of pronunciation in oral communication, the number of NNS teachers of English worldwide, and because of the communication needs among speakers of different varieties of English. This case study investigated the knowledge base of an experienced in-service NNS pronunciation teacher in an English-as-a-foreign-language context. Using qualitative data-gathering methods (e.g., classroom observation, semistructured interviews, and stimulated-recall interviews), and Shulman's Knowledge Base Framework, the study demonstrates that the knowledge base that allows an NNS teacher to implement pronunciation teaching is composed of categories of knowledge interrelated in complex ways. Building upon these findings, the study also uncovers how factors such as previous learning and teaching experiences shape the beliefs and pedagogical actions of such teacher in implementing pronunciation instruction.

De récentes études ont exploré la façon dont les connaissances, croyances et opinions pédagogiques des professeurs d'exercices de prononciation influent sur leurs pratiques en classe. Par ailleurs, de récentes recherches ont démontré l'efficacité des locutrices et locuteurs non natifs (NNS) dans l'enseignement de la prononciation. On sait toutefois très peu de chose sur la base de connaissances qui leur permet de mettre en cuvre un apprentissage de la prononciation. C'est là un domaine où une enquête plus poussée s'impose compte tenu du rôle central que joue la prononciation dans la communication orale, du nombre de locutrices et locuteurs non natifs qui enseignent l'anglais à travers le monde et des besoins de communication qui existent entre les locuteurs de plusieurs variétés d'anglais. La présente étude de cas examine la base de connaissances d'une professeure non native expérimentée qui enseigne la prononciation dans un contexte d'enseignement de l'anglais comme langue étrangère. À l'aide de méthodes de collecte de données qualitatives (par ex., l'observation en classe et des entrevues semi-structurées ou fondées sur la méthode du rappel stimulé) et du Knowledge Base Framework de Shulman, l'étude démontre que la base de connaissances qui permet à une enseignante non 
native de mettre en cuvre un cours de prononciation se compose de catégories de connaissances dont les interdépendances sont complexe. En se fondant sur ces conclusions, l'étude révèle également la façon dont des facteurs comme les expériences antérieures d'apprentissage et d'enseignement façonnent les croyances et les actions pédagogiques d'une enseignante particulière dans la mise en œuvre d'un cours de prononciation.

KEYWORDS: pronunciation teaching, teacher cognition, knowledge base of teaching, nonnativespeaking teachers

Research in second language teacher cognition (SLTC) recognizes the central role that past experiences in learning and teaching have in shaping teachers' own cognitive skills and beliefs regarding the teaching-learning process (e.g., Borg, 2003; Freeman \& Johnson, 1998; Kubanyiova \& Feryok, 2015). In recent years, there has been a growth in studies exploring the knowledge, beliefs, thoughts, attitudes, and perceptions of learning of second language (L2) pronunciation teachers (Baker, 2014; Baker \& Murphy, 2011; Burri \& Baker, 2019; Couper, 2016, 2017; Hismanoglu \& Hismanoglu, 2011). These studies are necessary to understand the classroom practices of pronunciation teachers, as many still operate by intuition or in an ad hoc manner (Derwing \& Munro, 2015; Foote, Holtby, \& Derwing, 2011; Levis, 2005; Murphy, 2014b). Despite key findings, the knowledge base of nonnative-speaking (NNS) pronunciation teachers has remained mostly unexamined (but see Buss, 2016; Couper, 2016). This is necessary to understand not only because of the general interest that L2 pronunciation teaching and research has regained (Lee, Jang, \& Plonsky, 2015; Thomson \& Derwing, 2015), but also because of the essential role that pronunciation plays in L2 oral communication (Darcy, 2018), the number of NNS teachers of English at present (Deng et al., 2009; Graddol, 2006; Miller, 2009), and the potential benefits that nonnative and intelligible models of L2 pronunciation could bring to the field (Murphy, 2014a, 2017). Thus, this study investigates the knowledge base of an experienced NNS pronunciation teacher in an English-as-a-foreign-language (EFL) context. The study takes into account the teacher's actual practices in the classroom, and it is a partial replication of Johnston and Goettsch's (2000) study of the knowledge base of grammar teachers, but with a focus on L2 pronunciation instruction. The purpose of the study was to investigate the aspects that constituted the knowledge base of an experienced NNS teacher that allowed her to implement pronunciation instruction, and how this teacher taught pronunciation in an EFL class. In the following pages, I present the relevant research that motivated the investigation followed by the methodological steps used to carry out the study, the main findings, and my discussion and concluding remarks. 


\section{Literature Review}

\section{Second Language Teacher Cognition}

Second language teacher cognition as a field seeks to "understand teachers' minds and emotions and the role these play in the process of becoming, being and developing as a teacher" with reference to "their personal, professional, social, cultural and historical contexts" (Borg, 2019; p. 20). This dimension of language teaching is characterized by "an often tacit, personally-held, practical system of mental constructs held by teachers and which are dynamic-i.e., defined and refined on the basis of educational and professional experiences throughout teachers' lives" (Borg, 2006; p. 35). These theoretical constructs are derived not only from teachers' formal, theoretical knowledge of linguistics or second language acquisition (SLA), but also from the central role that the activity of teaching itself plays in teachers' professional growth (Freeman \& Johnson, 1998). This knowledge is formed by a complexity of separate but interrelated categories of knowledge (Shulman, 1987).

While studies of SLTC have analyzed teachers' knowledge, beliefs, and actions about teaching different skills, studies of pronunciation teachers have only started to appear recently (see Baker \& Murphy, 2011; Murphy, $2014 \mathrm{~b}$ for summaries). Most of these studies have relied on reported practices, uncovering how a lack of training in different areas affects teachers' confidence in teaching and assessing pronunciation (e.g., Couper, 2016, 2017; Foote, Holtby, \& Derwing, 2011; Macdonald, 2002), and their implementation of appropriate instructional techniques (e.g., Buss, 2016; Hismanoglu \& Hismanoglu, 2010). In addition, research has also reported a preference in many NNS teachers for specific varieties of English as targets for instructional purposes-particularly inner-circle varieties as opposed to more common nonnative varieties from expanding-circle contexts (see Kachru, 1990; Sifakis \& Sougari, 2005; Timmis, 2002). More recent studies (e.g., Baker, 2011, 2014; Baker \& Burri, 2016) have taken into consideration not only reported information from teachers but also their actual practices in class, and they have demonstrated that training in pedagogical phonology is not only reflected in teachers' confidence to approach pronunciation instruction but also in their pedagogically oriented decisions in class - such as using a wider repertoire of teaching techniques.

\section{NNS Teachers in Teaching Pronunciation}

Although studies of SLTC of pronunciation teachers have started to gain attention in recent years (e.g., Baker, 2014; Burri \& Baker, 2019; Couper, 2017), the role of NNS teachers in L2 pronunciation has been explored to a considerably lesser extent (e.g., Burri, 2015; Couper, 2016; Levis, Sonsaat, Link, \& Barriuso, 2016; Murphy, 2014a). Although NNS teachers can be multicompetent and professional language users capable of implementing effec- 
tive L2 instruction equivalent to native-speaking (NS) teachers (e.g., Braine, 2005, 2010; Cook, 1999; Kamhi-Stein, 2014; Mahboob, 2004, 2010; Medgyes, 2017), their role in pronunciation instruction needs further investigation, as many NNS teachers feel reluctant to teach pronunciation due to concerns about their accent (e.g., Golombek \& Jordan, 2005; Timmis, 2002) or limited preparation in different areas such as phonetics, phonology, and pronunciation pedagogy (Murphy, 2014b). Such limitations have been reported of NNS teachers in EFL contexts such as Brazil (Buss, 2016), Uruguay (Couper, 2016), and Europe (Henderson et al., 2015), but also of NS teachers in ESL contexts such as Canada (Foote et al., 2011), Great Britain (Burgess \& Spencer, 2000), and New Zealand (Couper, 2017). Nevertheless, training in pronunciation pedagogy has demonstrated to be key to help NNS teachers develop cognitions about pronunciation instruction, but also more self-awareness and confidence about their own English to be able to implement effective techniques to teach pronunciation (see Burri, 2015; Burri \& Baker, 2019; Burri, Baker, \& Chen, 2017). Despite the limited research available, pronunciation specialists underscore that intelligible (i.e., actually understandable) and comprehensible (i.e., easy to understand) pronunciation models of NNS teachers represent a valuable resource for instruction because of their attainability as L2 speaker models, and their previous experiences as L2 learners (Derwing \& Munro, 2015; Murphy, 2014a, 2017). In addition, insights from NNS teachers represent significant pedagogical content that can be utilized for teacher training purposes (see Murphy, 2014a, 2017, 2018).

A recent study by Levis et al. (2016) demonstrated that NNS teachers can be as equally effective as NS teachers in implementing pronunciation instruction that leads to the development of comprehensible L2 speech. As claimed by Levis and colleagues, this demonstrates that effective pronunciation instruction depends on a teacher's knowledge base and not necessarily on their native language background. This finding supports the idea that being a native speaker of a language is not sufficient on its own to make a language teacher effective (Mahboob, 2010; Phillipson, 1992), but also that an NNS teacher can be qualified to teach any aspect of the language (Levis et al., 2016). However, the question remains: What enables NNS teachers to implement effective pronunciation instructional practices through their knowledge base?

It is important to note that teacher education specialists have called for more SLTC research that integrates teachers' beliefs with their actual classroom teaching practices (e.g., Baker \& Murphy, 2011; Borg, 2003, 2006; Freeman \& Johnson, 1998), considering that teachers' stated beliefs may be notably different from their actual practices (Basturkmen, Loewen, \& Ellis, 2004). Thus, this study was undertaken to complement previous studies that have investigated SLTC of pronunciation teachers taking into account actual teaching practices (e.g., Baker, 2014; Baker \& Burri, 2016), the SLTC of NNS teachers (e.g., Burri, 2015; Burri et al., 2017; Couper, 2016), and the pedagogi- 
cal potential of NNS teachers in pronunciation instruction (Murphy, 2014a, 2017), but also to address the gap in the literature regarding NNS pronunciation teachers. This study was devised to investigate what constitutes the knowledge base of an experienced NNS pronunciation teacher, and how such teacher approached L2 pronunciation instruction in an EFL context. The study was guided by two research questions:

Research Question 1 (RQ1): What constitutes the knowledge base of an experienced NNS pronunciation teacher?

Research Question 2 (RQ2): How does an NNS pronunciation teacher approach L2 pronunciation teaching?

\section{Conceptual Framework}

I analyzed the knowledge base of an experienced NNS pronunciation teacher using Shulman's (1987) Knowledge Base Framework. Given that the purpose of this study was to explore what constitutes the knowledge base of such a teacher, Shulman's conceptual framework seemed suitable because it allowed the analysis of different components of the knowledge base through discrete categories, as well as an empirical exploration of this teacher's knowledge through interviews, direct observations, and stimulated-recall interviewsamong other procedures. In addition to the analyses of teacher knowledge in areas such as science, mathematics, and higher education (e.g., Hill, Shilling, \& Ball, 2004; Justi \& Van Driel, 2005; McAlpine, Weston, Berthiaume, \& Fairbank-Roch, 2006), Shulman's framework has been used extensively in several SLTC studies (e.g., Gatbonton, 2008; Gorsuch \& Beglar, 2004; Johnston \& Goettsch, 2000). More specifically in pronunciation teaching, Baker's (2014) analysis of five pronunciation teachers in an English as a second language (ESL) program was the first empirical study to use this conceptual framework because of its suitability in the analyses of teacher knowledge through discrete categories of knowledge.

Shulman's framework presents teacher knowledge as a set of seven interrelated categories that refer to specific domains of knowledge in teaching: Content Knowledge, General Pedagogical Knowledge, Curriculum Knowledge, Pedagogical Content Knowledge, Knowledge of Learners and their Characteristics, Knowledge of Educational Contexts, and Knowledge of Educational Ends, Purposes, and Values. In L2 teaching, for instance, Content Knowledge refers to a teacher's knowledge about syntax, phonetics, phonology, and lexicon of the L2, among other linguistic areas. In contrast, Pedagogical Content Knowledge refers to the practical application of knowledge about language and linguistics to explain and transmit grammatical, lexical, or phonetic content to students. More specifically, in pronunciation teaching, Content Knowledge refers to the teacher's knowledge about phonetics and phonology (e.g., voicing, place, and 
manner of articulation of consonants, or tongue position in vowels), whereas Pedagogical Content Knowledge refers to teaching techniques to transmit such content (e.g., asking students to place their upper teeth on their lower lip "like biting your lip" to produce a labio-dental sound). These categories of knowledge from Shulman's framework were also used to code data (see Data Collection and Analyses section below).

\section{Research Design}

I used a qualitative case study design for this investigation, as it allows an in-depth understanding of a specific phenomenon by showing a detailed portrait of the complexity of real-life events (Merriam, 2009). A case study design seemed suitable to investigate the knowledge base of an NNS pronunciation teacher because, as pointed out by Stake (1995), a significant amount of information about a phenomenon can be learned through a single case. The study is explanatory in nature because I used information obtained through different sources (e.g., interviews, classroom observation, audio-video recordings) to understand the factors composing the teacher's knowledge base and the rationale behind her decisions in class (Richards, 2003). In addition, I used purposeful sampling as a great volume of rich information can be obtained by purposefully selecting a participant that is directly involved with the phenomenon in question - in this case, the operations of an NNS pronunciation teacher in an EFL context (see Patton, 2002).

\section{Data Collection and Analyses}

After obtaining approval from the ethics committee of the school and consent from the teacher participant, I started data collection through classroom observation, interviews, audio-video recordings, and journals. I observed the teacher in class during one semester in its entirety ( 15 weeks). Throughout this semester, I carried out 15 observations of $4 \mathrm{hr}$ per week, as the class met once per week for $4 \mathrm{hr}$ (see the Research Context and Study Participant section below). I carried out these observations as a nonparticipant to document-through field notes using thick description - the interaction between the teacher and her students (Richards, 2003). I documented the teacher's explicit explanations, error corrections, teaching techniques, and the materials she brought to the class. I also documented her role in class when facilitating individual and group activities, or using technology such as videos or audio files in the language lab.

I audio recorded all the classes for transcription and analysis. I also video recorded 2 weeks of classes (i.e., two different classes during Weeks 6 and 13) for a total of $8 \mathrm{hr}$ of video recording (i.e., $4 \mathrm{hr}$ per week). Only two classes were video recorded to avoid being too invasive with the data collection during class. Specific clips from these video recordings were used in two stimulated-recall interviews with the teacher to understand the rationale 
behind specific actions in class (Gass \& Mackey, 2000). The clips were selected based on explicit phonetic explanations, error correction techniques, or the implementation of group activities. I asked the teacher about the reasons behind those actions (e.g., Why did you explain the difference between these two sounds using those examples on the board?), and I also asked for further explanation of responses to understand her perspective (e.g., Why was it important to explain the difference between these two sounds in such a way? Could you tell me more about that?). These two stimulated-recall interviews took place during the middle (Week 8) and at the end of the semester (Week 17, after the course ended), respectively. They were audio recorded and transcribed, and they lasted a little less than an hour.

In addition to the classroom observations, and the stimulated-recall interviews, I conducted three semistructured interviews with the teacher at the beginning (Week 2), middle (Week 8), and end of the course (Week 17 after the course was finished) to understand her previous experiences and beliefs about pronunciation and L2 teaching in general, as well as to gauge her sense of progress of the class (Borg, 2003; Freeman \& Johnson, 1998; Kubanyiova \& Feryok, 2015; Patton, 2002). These interviews were audio recorded and transcribed, and scheduled during different parts of the semester to get the teacher's perspective about progress being made by her and her learners. I showed the teacher all the transcripts from both semistructured and stimulated-recall interviews to confirm their accuracy. Another set of data came from the journal entries I composed following each class observation. These journal entries included my impressions about the teacher and what I observed in class. Writing these journals permitted a continuous dialogue between my data collection efforts, the process of my writing, and my data analyses (see Holliday, 2010).

For the data analysis, I used my field notes, journal entries, and transcriptions from the teacher interviews and classroom audio recordings to code similar common themes and categories (Merriam, 2009; Richards, 2003). The coding was done using three specific categories from Shulman's (1987) framework: Content Knowledge, Pedagogical Content Knowledge, and Knowledge of Learners and their Characteristics, as in similar studies (e.g., Johnston \& Goettsch, 2000). One difficulty with the coding process is that many findings overlapped in these categories. However, it is precisely this overlapping that shows the complexity of teacher knowledge base. Thus, as has been done in other studies (e.g., Johnston \& Goettsch, 2000), I added a fourth new category: Knowledge of Pronunciation Teaching: Different Categories Interrelated. This category is an amalgamation of the first three categories from Shulman's model, and it encapsulates the interrelationships among the categories and the complexity of the knowledge base of an NNS teacher, as also demonstrated by Johnston and Goettsch in the area of grammar teaching. 


\section{Research Context and Study Participant}

The study was carried out in a stand-alone pronunciation class, which is part of a 2-year Associate program in English at a state university in Costa Rica. The school is a branch campus located in a small town with about 1,000 students enrolled in undergraduate programs in computer engineering, business, Teaching English as a foreign language (TEFL), English, and tourism. The pronunciation class in this study is the first of three pronunciation courses in the program. The first course focuses on vowels and prosodic aspects (word and sentence stress, rhythm), the second one focuses on consonants and intonation, and the third course reviews all segmentals and suprasegmentals. There were 27 students enrolled in the class, and they were L1-Spanish speakers (17 to 21 years of age). This was the first semester in the program for most of these students, who were also taking grammar, listening-speaking, and integrated-skills classes at the moment of the study. ${ }^{1}$ The class lasted a total of 16 weeks, and it met 1 day per week for $4 \mathrm{hr}$ during the evening, as the majority of students worked during the day. Class time was distributed $2 \mathrm{hr}$ in a regular classroom, and $2 \mathrm{hr}$ in a traditional language lab.

It is necessary to mention that I first gained access to the school and the class due to my familiarity with the program as a faculty member for the school's TEFL major at the time of the study, and I occasionally taught classes in the Associate program, too. The teacher for this class was Maria, a senior instructor in the program with 17 years of teaching experience. ${ }^{2}$ Maria had been my colleague in another language program in the same school, which offered English classes to people outside of the university. She has a BA and MA in TEFL from Costa Rican universities, and she has experience teaching English at the college level, at private language schools, and in public and private elementary and secondary schools. In fact, she was a regular EFL teacher in a public elementary school during the mornings and afternoons, and she taught college-level classes in the evenings. In the following section, I will present the main findings from this study, followed by a general discussion and implications for pronunciation instruction and teacher training purposes.

\section{Findings}

\section{Content Knowledge: Basic Knowledge of English Phonetics and Phonology}

As reported in previous studies, many teachers do not receive much training in areas related to the teaching of pronunciation (e.g., phonetics and phonology; see Murphy, 2014b). This was also Maria's case, whose formal training did not include specific phonetics-phonology, or pedagogical phonology courses, but only a couple of general linguistics courses that touched briefly on phonetics and phonology. Maria, however, seemed to have a good grasp 
of basic English phonetics and phonology to teach this class, which allowed her to go beyond mere comparisons of vowels to explain content that she considered important for learners to master. For instance, Maria explained vowel quality differences through minimal pairs and explained to learners different characteristics of vowels (e.g., tense and lax), and emphasizing how specific phonetic environments could affect their production. For example, she explained vowel quality differences using minimal pairs, and she also stressed that differences in length depended on the presence of voiced or voiceless consonants after a vowel. She explained this with the words [sut] and [su:d] and then asked learners to repeat after her (see Appendix A for this explanation).

As shown in the excerpt below, during her explanations, Maria found ways to go beyond individual sounds to explain content related to suprasegmentals, introduce problematic consonant clusters, or present phonological rules such as reviewing the pronunciation of the final morpheme -ed in past-tense regular verbs:

Maria:

so we have three different forms to pronounce the -ed ending, right? Do you remember which are the three forms?

Student1:

[id]

Maria:

ok, we have one is [Id]

Students:

[id]

Maria:

not [id], [Id]

Students:

[Id]

Maria:

aha, the other one is [d]

Students:

[d]

Maria:

and the other one is $[\mathrm{t}]$

Students:

[t]

Maria:

$\mathrm{ok}$, when do we pronounce $[\mathrm{t}]$ ?

Student2:

when the last...

Student3:

when the ending of the letter is, voiceless

Maria:

ok, when the -ed is added to a word that finishes in?

Students:

voiceless

Maria:

a voiceless sound! For example [teacher writes on the board] "walked," we don't have to carry-I mean, we don't have to care about the last letter in the word. We have to care about the last sound, ok? So here the last sound is $[\mathrm{k}],[\mathrm{k}::]$

Students:

$[\mathrm{k}::]$

Maria:

$\mathrm{ok},[\mathrm{k}]$ is a voiceless sound. So when we add the -ed [teacher writes the phonetic transcription of the word "walked" on the board], it sounds [wokt]. (Class, Week 3) 
Maria stated that she felt quite confident with her knowledge of phonetics and phonology, and she saw it as one of her best assets to teach a course like this:

I think that is, how can I say, my biggest strength ... aspects related to pronunciation and phonetics and phonology, and intonation and all that, I guess I'm more familiar with those. I think that my knowledge is let's say quite enough to be able to teach. Of course I won't say that I know everything because it's impossible, and I won't say that I'm like very wise because I'm not. But I try to do my best because it [pronunciation] is something that I like and that I just enjoy. (Maria, Interview 1)

I found this revelation from Maria interesting given the fact that her training in phonetics and phonology was minimal. However, as an L2 learner, Maria did take pronunciation classes (similar to this course) as part of her training where she was taught pronunciation explicitly. These courses seemed to constitute a major influence on her teaching as they provided not just a bulk of knowledge about English pronunciation aspects, but also a foundation for pronunciation instruction in her career. ${ }^{3}$ As explained in the next section, this was evidenced in some of the techniques she implemented in class.

\section{Pedagogical Content Knowledge: Rationale Behind the Use of Different Techniques}

Maria had a repertoire of techniques to deliver instruction that consisted of explicit phonetic explanations, video and audio files from different sources, pair/group activities, and games. I was interested in learning about the sources of some of her techniques for explaining concepts, and Maria told me a former college professor had an important influence on her, and that she learned many techniques from him that she incorporated in her own pronunciation classes:

I think that he was a very good professor. He knew a lot, and he was able to transmit that knowledge to his students. ... He used to draw on the board, he was very skillful at drawing and he could draw the phonetic or speech organs in a diagram, and I remember that he drew the tongue and the movements of the tongue on the board, and I remember that it was very useful because when you see things on the board you remember them better... I guess that the way you learn is like a basis, like very important, related to the way you teach. Because you get what you liked from the learning experience, and you can even improve it in your teaching process. (Maria, Interview 1) 
I was able to see some of these same techniques in Maria's class. She constantly used the board to provide phonetic transcriptions, or draw sagittal figures to point out places of articulation. For example, she used the board to mark sentences with up and down arrows to explain intonation patterns, and she further explained to the students that questions and statements could carry different intonation, or that a statement could turn into a question by using rising intonation (see Appendix B for this example). In addition to mentioning that these were techniques she learned from a former professor, Maria also explained to me that the purpose of drawing intonation arrows on the board was to appeal to different types of students because they learn in different ways, and some need to see visual examples on the board. This, she said, is something that she learned from experience (see Appendix C). It is important to mention that even though Maria incorporated a variety of different techniques she learned from former professors, she learned other techniques through her own experience as a teacher that helped transmit her knowledge of pronunciation content to her students. For example, she implemented board games in class in which students had to compete and come up with the right phonetic symbol for specific words they heard. Maria said that the purpose of some of these activities was to make learners aware of differences between the number of sounds and letters in words. She explained that, in her experience, this was an aspect where students struggled at the beginning of her pronunciation courses, so she incorporated this type of activity to help learners understand such differences.

Maria usually started her class by introducing phonetic concepts explicitly, providing handouts that presented phonetic content and explaining such content in her own words and with examples on the board. After her explanation, she usually presented a video with more examples to reinforce the concepts she presented. After introducing content, Maria used different sets of listening tasks for the students to discriminate vowel sounds through minimal pair exercises, isolated or embedded in sentence or phrasal contexts. Finally, the students worked in pairs or small groups, reading dialogues aloud. Sometimes they completed information-gap activities, or presented short role-plays in front of the class.

As mentioned previously, Maria constantly reinforced her explanations through different forms of visual aids (e.g., use of the board, videos, charts, and diagrams). She taught phonetic content explicitly and provided visual reinforcement through the use of phonetic transcription. This use of transcription was useful when clarifying content, as in the following passage where a student could not understand the difference in pronunciation between "send" and "sand":

Maria: number five? Number five is incorrect

Student7: $\quad$ why?? ((laughs)) 


$\begin{array}{ll}\text { Maria: } & \text { because it is not "sand the letter" but "send the letter." Do you want me } \\ & \text { to write the words on the board? } \\ \text { Students: } & \text { ok } \\ \text { Maria: } & \text { going to . . } \\ \text { Student?: } & \text { (?) } \\ \text { Maria: } & \text { [sæich one? Number five is "please send the letter," but they said "sand" } \\ & \text { I don't understand } \\ \text { Student?: } & \text { you don't get it? Ok wait, don't worry } \\ \text { Maria: } & \text { can you write the the . . . } \\ \text { Student?: } & \text { the whole thing? } \\ \text { Maria: } & \text { yes please } \\ \text { Student?: } & \text { [the teacher writes the complete sentence on the board and uses phonetic } \\ \text { transcription in these two words to show their difference] the word there } \\ \text { was "sand" [sænd], not "send" [scnd] ok? So number five was "please } \\ \text { sand the letter," but it cannot be "sand" it was supposed to be "send," } \\ \text { ok? That's why it was incorrect. (Class, Week 5) }\end{array}$

As seen in this passage, the students were able to understand the use of transcription for the clarification of content. At the beginning of the semester, Maria taught her students the International Phonetic Alphabet, and she asked them to find the equivalent of each symbol in their own dictionaries. Maria explained that the purpose of this was to promote awareness of differences between sounds, and to help students learn the sounds by "seeing" them through visual representation. To reinforce such awareness, Maria brought games to the class that involved the use of phonetic symbols (e.g., a bingo game to reinforce the use of phonetic symbols and differences between sounds).

I was interested in understanding some of the reasons behind Maria's use of phonetic terminology with her students, and the explicit teaching of different phonetic phenomena in her class. She mentioned this was done to raise awareness in learners of phonetic issues, and that such awareness gave them more control of their own learning (see Appendix D). Taking more control of their own learning was something that her students did in class while working in small groups. Her students usually worked in pairs or groups of three, and Maria indicated this was done so they could help each other with their own pronunciation problems. She said it was easier for students to notice pronunciation problems in different tasks where they could give feedback to each other (see Appendix E). In fact, different pair and group activities implemented in class prompted the students to help each other with pronunciation challenges (see Appendix $\mathrm{F}$ for an example of students helping each other).

Maria also encouraged the students to work on other types of activities where they could put their knowledge into practice more spontaneously. For 
example, she assigned group activities or oral presentations in class where learners talked about different issues, prompting more spontaneous discussion. She explained the reason behind implementing oral presentations in class in the following way:

The idea was to make them speak, and to make them pronounce the sounds correctly without knowing that they were doing so. Because they were talking about a different topic, and the topic was not related to pronunciation, it was a topic that they liked because they choose their own topics. Of course I was evaluating the pronunciation of sounds, but they were not like very aware of every single sound and every single word because they were thinking about the general idea they wanted to transmit ... when you go to the real world, when you go to a country where everybody speaks English, you're not going to be thinking "oh my God, how do I have to place my tongue, and what about the lips and the jaw for this, for the pronunciation of this sound." They just have to do it, so the idea was just to make them feel like in a real-life situation, that was basically the idea. (Maria, Interview 3)

It is worth noting that what Maria was referring to in her explanation was the need to implement communicative activities in class focused on meaning where her students could develop fluency. The fact that students got to practice sounds under controlled conditions did not seem enough to help them develop clear pronunciation in "real world" situations. In fact, raising awareness of pronunciation problems that could take place in the real world was something she frequently brought to her students' attention.

Maria constantly used videos and audio sources for teaching pronunciation purposes. As she is a competent L2 user with intelligible English pronunciation, I asked why she seemed to rely on the use of such videos and audio files in the course. She stated the main reason for this was to expose students to different varieties of English. She said that

it is also important for learners to get accustomed to different voices, to different pronunciations and to different people speaking English ... I try to look for videos or I have CDs with other people speaking, just to make them [the students] aware that I'm not the only person who speaks English and that they can't get accustomed only to my speech. (Maria, Interview 2)

It is important to mention that the videos and audio files Maria brought to class were not always intended for pronunciation teaching purposes. Sometimes, these were materials from news or television shows, as in a video clip from the show Modern Family. One of the show's characters has a notable Spanish accent, and showing the video clip prompted a discussion about the way pronunciation deviances can cause communication problems in real 
life. Given the fact that Maria wanted to make her learners aware of different accents, I became interested in learning what she wanted her students to achieve. When I asked her about this, the debate about native accents versus intelligibility came up, and Maria seemed to have a clear position about it:

I want my students to be fluent and speak as much as possible, and to speak as perfect or as good as possible ... the idea of sounding like a native speaker is very difficult because I'm not a native speaker. However, I guess the most important point is to be able to communicate ... I think that the most important thing is to be able to communicate fluently and in a comprehensible manner. (Maria, Interview 2)

It was interesting to learn not only the rationale behind the use of these materials and activities in Maria's pronunciation class but also her own position about being an NNS teacher and what she wanted learners to achieve. In fact, being a former language learner allowed her to anticipate specific pronunciation difficulties in her students.

\section{Knowledge of Learners and Their Characteristics: Familiarity with Learners' Needs and Background}

As an NNS who went through the language-learning process herself, Maria was able to anticipate students' pronunciation difficulties. This allowed her to reinforce areas that were difficult for learners, particularly in understanding differences between the English and Spanish phonetic/phonemic inventory. For example, she explained to the students that the schwa sound was a common vowel in English, but that many L1-Spanish learners tended to confuse it with vowels such as [a], [ $\varepsilon$ ], or [i], which could cause communication problems (see Appendix $G$ for this explanation). Maria explained her rationale for addressing these phonetic issues explicitly not only because of the complexity of the English sounds themselves, but also because of similarities with Spanish sounds. She further added that

sometimes we have a similar sound in Spanish, so for them [students] it's easier to get it. But there are other sounds, like the schwa sound, or the $[\Lambda]$ which we don't have in Spanish, so I think that for them it's like kind of more difficult to get. (Maria, Interview 3)

Having knowledge of pronunciation phenomena and anticipating possible problems with her students were key teaching assets that gave Maria confidence to teach pronunciation in spite of difficulties she experienced in previous jobs because of being an NNS teacher-such as job discrimination.

Maria was aware that being an NNS teacher could be used to her advantage in teaching. She said she felt confident teaching any skills in English-including pronunciation-despite the job discrimination she had faced 
previously for being an NNS teacher. Earlier in her career, she said that a parent complained to the principal of her school that she was "unqualified" to teach because she was an NNS. However, she reported that at the end of the school year, the same parent approached her and apologized because his child had actually learned a great deal, more so than in previous years. It is important to stress that the fact that Maria had been an L2 learner herself added to the other important characteristics that made her a confident L2 pronunciation teacher, such as her knowledge of phonetics and phonology, and command of different teaching techniques to implement in class. These characteristics were often deeply related to each other, which is presented in the following section.

\section{Knowledge of Pronunciation Teaching: Different Categories Interrelated}

The first three categories of knowledge presented above overlapped with each other in interesting ways. Maria demonstrated content knowledge, pedagogical content knowledge, and knowledge of learners and their characteristics. However, at times, her knowledge, beliefs, and actions about pronunciation teaching demonstrated that the three categories were intertwined-just as they were for the teachers in Johnston and Goettsch (2000). For instance, the following class passage in which Maria explained the difference between [b] and $[v]$, and the follow-up comment about such explanation represent a clear example of overlapping between categories:

Maria: in Spanish we don't make any difference between [the first sound of] "burro" (donkey) and [first sound of] "vaca" (cow) right? We say both words exactly in the same way, but in English there's a difference. This one [teacher points out the sound [b] on the board] is [b::] [b::] aha

Students: $\quad[\mathrm{b}::]$

Maria: $\quad$ it's called bilabial because it's produced with both lips, ok? The other one is [v] labiodental. It is produced with the lower lip, and your upper teeth, [v] [v:]

Students: $\quad[\mathrm{v}::][\mathrm{v}::]$

Maria: $\quad$ it's very similar to [f], the only difference is that this is voiced, and this one is voiceless, ok? (Class, Week 8)

Sometimes in Spanish we produce sounds and we don't pay attention to anything. Because, I mean, it's just natural, we just do it normally. We don't pay attention to this because our Spanish is our Spanish, we don't do anything. But I guess that sometimes we need to be aware of the production of the sound in order to produce it correctly because sometimes the lip position changes from one sound to another, so we need to know the difference and we need to know why. For example, let's say we're going to be pronouncing [a] and we need to have the mouth completely opened, we can't do it with 
the mouth closed because it would sound like a schwa, this kind of things. (Maria, Interview 2)

This explanation in class and Maria's rationale behind it demonstrates that, as a teacher, her content knowledge allowed her to point out phonetic differences between consonants [b] and [v]. Such knowledge consisted of awareness of phonetic differences between sounds in terms of place and manner of articulation as well as differences of voicing with other similar sounds (e.g., [f] and [v]). However, more than just knowledge of different phonetic features of L2 sounds, her knowledge of students' L1 allowed her to anticipate possible problems they could encounter when articulating these consonants, particularly because of their similarity in their own Spanish dialect. In addition, explicitly showing students phonetic differences on the board in terms of place and manner of articulation, coming up with specific examples she was aware her students knew (e.g., the words burro and vaca), and anticipating problems by showing their counterpart in Spanish were ways to make learners aware of differences between their L1 and L2. As Maria stated, pronunciation instruction should make learners aware of these differences to articulate sounds properly because speaking an L2, at the beginning stages, is not like speaking an L1 where the sounds are articulated automatically. These examples demonstrated that differences in categories of knowledge are blurred in many cases because they are interrelated with and depend on each other. That is, Maria possessed content knowledge of phonetic differences between sounds, but it was her pedagogical content knowledge that allowed her to transmit what she considered her students needed to know about such phonetic differences using explicit instruction and appropriate examples - taking into account her knowledge about the students' own L1 to make the content easier for them to understand.

To summarize, Maria was an NNS pronunciation teacher whose training in phonetics and phonology was minimum, but whose command in this area-even at a basic level-allowed her to teach pronunciation using different techniques: by making learners aware of different L2 features and by using her knowledge of differences between the students' L1 and L2 that could hamper learning. In the following section, I will provide a discussion of the relevance of these aspects and their implications for pronunciation teaching and teacher training purposes.

\section{Discussion}

The findings presented previously demonstrate that Maria is an experienced and confident NNS pronunciation teacher. The classroom examples of her delivery of instruction and her rationale behind the pedagogical actions and decisions she made in class demonstrate that what makes her confident in pronunciation teaching is the complexity of her knowledge base of teaching. 
Going back to RQ1, What constitutes the knowledge base of an NNS pronunciation teacher?, we can claim that the knowledge base of this NNS pronunciation teacher goes beyond knowledge of phonetics and phonology and beyond knowledge of different techniques such as repetition to make learners practice L2 sounds. Instead, it is an amalgam of aspects interrelated in complex ways that solidify the knowledge that a teacher needs to deliver pronunciation instruction. That is, it is a bulk of knowledge composed of theoretical content and awareness of instructional techniques shaped by the needs of the students, which allows her to implement pronunciation instruction systematically (e.g., using a variety of techniques to explain phonetic content, implementing activities where students interact with each other, or activities where they produce the L2 spontaneously). This is not that different from what teachers who specialize in teaching other skills (e.g., grammar) possess (e.g., Borg, 1998; Johnston \& Goettsch, 2000).

Although it is possible to say that Maria's knowledge base aligns with the different categories represented in Shulman's (1987) framework, it is also worth noting that much of this knowledge came not only from her training, but rather from her previous experiences as a learner and teacher. That is, in spite of no formal training in pedagogical phonology, she had basic linguistic training and experience (both as a language learner and teacher) that allowed her to master a bulk of phonetic content knowledge and pedagogical content knowledge that enabled her to implement what she considered appropriate for students to become clear L2 speakers. Maria not only focused on the main phonetic content of the course (i.e., vowels and prosody) but also went beyond such content (e.g., introducing problematic consonants for students, voicing, intonation, and the influence of contextual phonetic factors when necessary) and implemented teaching techniques that could give learners opportunities to develop intelligible and comprehensible L2 speech, for instance, combining activities focusing on form and meaning, or raising awareness in learners of differences between features of their L1 and L2. After all, previous research and pedagogical literature in L2 pronunciation have pointed out the importance of integrating explicit instruction with controlled and communicative tasks (Celce-Murcia, Brinton, Goodwin, \& Griner, 2010; Zielinski \& Yates, 2014), and the positive relationship between awareness of L2 forms and gains in pronunciation learning (Kennedy \& Trofimovich, 2010; Venkatagiri \& Levis, 2007).

It is important to mention that it is precisely this combination of experience as a language learner and teacher that gave Maria knowledge to implement explicit phonetic instruction and combine it with techniques where her students could practice the language more spontaneously as in "real life" situations. For instance, she implemented a balance between explicit instruction, controlled techniques, and more meaning-oriented activities - which is a combination suitable to developing L2 learning, according to the SLA literature, and also promoted by pronunciation specialists (Celce-Murcia 
et al., 2010; Darcy, 2018; Ellis \& Shintani, 2014; Levis \& Grant, 2003; Sicola \& Darcy, 2015). It is necessary to understand the origin of the knowledge base that allowed Maria to implement pronunciation in this way. Previous research has demonstrated that teachers who received training use a wider variety of techniques, beyond repetition, to implement pronunciation instruction (Baker, 2014). Nevertheless, the results presented here demonstrate that an experienced teacher can also develop an important part of such knowledge based on teaching and learning experiences. Whereas it is true that training in pronunciation pedagogy is essential for teachers to ground their knowledge base and make the best pedagogical decisions for instruction (see Murphy, 2014b), and such training can give NS and NNS teachers tools and confidence to implement appropriate pronunciation teaching techniques (Burri, 2015; Burri \& Baker, 2019; Burri et al., 2017), these results are aligned with previous claims that many teachers learn how to teach through the act of teaching itself, and that their knowledge base is mainly developed through experiences in the classroom (e.g., Freeman \& Johnson, 1998; Johnson, 1999; Gatbonton, 2008). It is important to remember that in the case of teachers such as Maria, these previous experiences in the classroom are both teaching and learning experiences-as NNS teachers were learners who went through the process of learning an L2 (Borg, 2003; Braine, 2005, 2010; Kubanyiova \& Feryok, 2015).

One additional point about Maria's experience as a learner is that it allowed her to identify areas in pronunciation that might be difficult for students. In fact, this is one issue that has been previously pointed out in the literature: NNS teachers can be effective role models of what a competent L2 speaker can do, and their previous learning experience gives them tools to address different issues their students encounter in class. This is a feature of the multicompetent nature of many NNS teachers that they can use to their advantage in pronunciation teaching, just as they do when teaching other skills (see Braine, 2005, 2010; Cook, 1999; Murphy, 2017; Nemtchinova, 2005).

As for RQ2, How does an NNS teacher approach L2 pronunciation teaching?, the findings presented demonstrate important ways in which this teacher approached pronunciation instruction. For example, Maria not only provided explicit phonetic instruction and implemented controlled and guided tasks (e.g., reading scripted dialogues in pairs), but sometimes she also put into practice more meaning-oriented activities to help her students develop fluency (e.g., oral presentations). While many pronunciation teachers have a preference for the use of controlled techniques such as repetition over more free-form communicative tasks (see Baker, 2014; Hismanoglu \& Hismanoglu, 2010), and what Maria did in class is not that different from what many other pronunciation teachers do (e.g., relying on controlled activities most of the time), it is important to stress that her teaching style did not consist only of controlled and guided techniques, but also a combination that included communicative activities - though to a lesser extent. In addition, Maria's comments about the need to make learners balance their knowledge of 
articulation of proper pronunciation while speaking "without thinking about it" as in the "real world" is proof that the knowledge base of a teacher allows her to make pedagogical decisions based on her students' needs; for example, producing sounds properly not only in controlled tasks but also in spontaneous situations like the ones they will encounter outside of class. Such a combination is in line with what research and the pedagogical literature suggest to develop fluent, intelligible, and comprehensible L2 speech (Celce-Murcia et al., 2010; DeKeyser, 1998; Gatbonton \& Segalowitz, 2005; Zielinski \& Yates, 2014).

Another important aspect shown in these results is Maria's use of a technology component in class (e.g., videos, different audio sources) not only to expose learners to different varieties of English but to raise awareness of the linguistic features of English accents and how pronunciation deviances can create communication problems in the real world (see Maria's comments about using different media for such purposes). While it may sound like a technological component is merely a way for Maria to compensate for the presence of a foreign accent in her own speech, exposing L2 learners to different L1 and L2 varieties of English is something that should be encouraged among pronunciation teachers in general (see Murphy, 2014a, 2017). This is particularly important at a time when L2 speakers of English outnumber L1 speakers (Deng et al., 2009; Graddol, 2006; Miller, 2009) and when effective communication is essential in different situations between speakers of inner, outer, and expanding circles (see Kachru, 1990; Jenkins, 2006). In addition, it is necessary to stress Maria's position about her own accent and her NNS status. Whereas previous research has pointed out that many NNS teachers may not feel confident teaching pronunciation because of concerns about their own accent (e.g., Couper, 2016; Golombek \& Jordan, 2005), the findings obtained in this study portray a more positive view: a confident NNS teacher whose complex knowledge base allows her to teach pronunciation with the goal of helping learners develop intelligible and comprehensible speech. This is a more realistic goal based on her own experience and beliefs, and one that is aligned with previous research (see Derwing \& Munro, 2015; Levis, 2005).

\section{Limitations, Future Research Directions, and Conclusion}

Although this study presents a picture of the way an experienced NNS teacher implemented pronunciation teaching in an actual class, there are still limitations that could be addressed in future research to fully understand the complexity of the knowledge base of NNS pronunciation teachers. Although this study presented the case of a single teacher, future research involving more teachers could make a stronger case by presenting commonalities in the knowledge base of other NNS pronunciation teachers. In addition, future studies with NNS teachers in different EFL contexts, in ESL contexts, or with different years of experience (novice vs. senior NNS teachers) could provide 
more information about challenges for teachers in pronunciation instruction. Despite these limitations, and the fact that this study analyzed one single teacher in a specific context, it is still important to consider how the singularities of this case study could provide relevant information for other NNS pronunciation teachers in similar contexts (see Merriam, 2009; Stake, 1995).

The findings of this study also disentangle characteristics of a confident and experienced pronunciation teacher that could be important to take into consideration for teacher education purposes. Basic knowledge of English phonetics and phonology, knowledge of different teaching techniques anchored in L2 speech development research, and knowledge of phonetic phenomena that helps learners develop fluent, intelligible, and comprehensible L2 speech are necessary pillars for any program or course intended to prepare teachers for L2 pronunciation teaching (see Murphy, 2018). At the same time, these results suggest that both NNS and NS teachers could benefit from pedagogical phonology courses. Although the teacher in this study did not take such a course as part of her training or implemented commonly used techniques in contemporary pronunciation pedagogy (e.g., kinesthetic and tactile reinforcement), but instead implemented techniques based on her considerable experience, this study raises the question as to what additional benefits teachers could gain if they were as properly trained in pronunciation pedagogy as preservice teachers (see Burri, 2015; Burri \& Baker, 2019; Johnson, 1994; Wyatt, 2009).

Finally, these results represent an additional call for a growing movement in Teaching English to speakers of other languages (TESOL) and applied linguistics that seeks more involvement of NNS teachers in pronunciation instruction (see Levis et al., 2016; Murphy, 2014a, 2017). More training could increase NNS teachers' confidence to empower them to teach pronunciation. At the same time, the implementation of intelligible NNS models of L2 pronunciation could help equip ESL and EFL learners with intelligible and comprehensible pronunciation skills to tackle the communicative demands of English speakers from different cultural and linguistic backgrounds in the globalized world of the 21st century.

Notes

1. Students enroll in this Associate program because English is a good asset to complement other majors (e.g., business, computer engineering, or tourism), or to obtain a better job as the Costa Rican economy in rural areas like this part of the country depends on tourism. Because this was their first semester in the program, the majority of students came directly from secondary schools, and their oral proficiency tended to be very basic. This is due to the fact that students in Costa Rican secondary schools take a national test based on reading comprehension, and instruction usually 
focuses on reading comprehension and grammar at the expense of other areas such as oral skills.

2. All the names used in this study are pseudonyms to protect the participants' identities.

3. The undergraduate program in teaching English as a foreign language (EFL) that Maria took consists of three distinct, interrelated modules: (a) attaining an advanced proficiency level in the language; (b) learning different aspects about the language, such as linguistics and second language acquisition (SLA); and (c) learning how to teach the language through pedagogical courses.

\section{Acknowledgements}

I would like to thank Yendry Alvarado, Lena Barrantes, John Murphy, and the anonymous reviewers for their comments and suggestions on previous versions of this manuscript. All errors remain my own. I would also like to thank Maria and her pronunciation students for allowing me to carry out this study in their class.

\section{The Author}

Joshua Gordon is assistant professor of Teaching English to speakers of other languages (TESOL) and Applied Linguistics in the Department of Languages and Literatures at the University of Northern lowa. He has taught English as a second language (ESL), English as a foreign language (EFL), and Spanish as a foreign language. He has trained preservice and in-service ESL and EFL teachers in the United States and in Costa Rica. His research interests include second language (L2) phonology and L2 pedagogy, particularly the interface between both areas in the teaching and learning of oral skills.

\section{References}

Baker, A. (2011). Discourse prosody and teachers' stated beliefs and practices. TESOL Journal, 2, 263-292. https://doi.org/10.5054/tj.2011.259955

Baker, A. (2014). Exploring teachers' knowledge of second language pronunciation techniques: Teacher cognitions, observed classroom practices, and student perceptions. TESOL Quarterly, 48, 136-163. https://doi.org/10.1002/tesq.99

Baker, A., \& Burri, M. (2016). Feedback on second language pronunciation: A case study of EAP teachers' beliefs and practices. Australian Journal of Teacher Education, 41, 1-19. https://doi. org/10.14221/ajte.2016v41n6.1

Baker, A., \& Murphy, J. (2011). Knowledge base of pronunciation teaching: Staking out the territory. TESL Canada Journal, 28, 29-50. https://doi.org/10.18806/tesl.v28i2.1071

Basturkmen, H., Loewen, S., \& Ellis, R. (2004). Teachers' stated beliefs about incidental focus on form and their classroom practices. Applied Linguistics, 25, 243-272. https://doi.org/10.1093/ applin/25.2.243

Borg, S. (1998). Teachers' pedagogical systems and grammar teaching: A qualitative study. TESOL Quarterly, 32, 9-38. https://doi.org/10.2307/3587900

Borg, S. (2003). Teacher cognition in language teaching: A review of research on what language teachers think, know, believe, and do. Language Teaching, 36, 81-109. https://doi.org/10.1017/ S0261444803001903

Borg, S. (2006). Teacher cognition and language education: Research and practice. London: Continuum.

Borg, S. (2019). Language teacher cognition: Perspectives and debates. In X. Gao (Ed.), Second handbook of English language teaching (pp. 1-23). Cham, Switzerland: Springer. 
Braine, G. (2005). A history of research on non-native speaker English teachers. In E. Llurda (Ed.), Non-native language teachers: Perceptions, challenges, and contributions to the profession (pp. 13-23). New York: Springer.

Braine, G. (2010). Nonnative speaker English teachers: Research, pedagogy, and professional growth. New York: Routledge.

Burgess, J., \& Spencer, S. (2000). Phonology and pronunciation in integrated language teaching and teacher education. System, 28, 191-215. https://doi.org/10.1016/S0346-251X(00)00007-5

Burri, M. (2015). Student teachers' cognition about L2 pronunciation instruction: A case study. Australian Journal of Teacher Education, 40, 66-87. https://doi.org/10.14221/ajte.2015v40n10.5

Burri, M., \& Baker, A. (2019). "I never imagined" pronunciation as "such an interesting thing": Student-teacher perceptions of innovative practices. International Journal of Applied Linguistics, 29, 95-108. https://doi.org/10.1111/ijal.12247

Burri, M., Baker, A., \& Chen, H. (2017). "I feel like having a nervous breakdown": Pre-service and in-service teachers developing beliefs and knowledge about pronunciation instruction. Journal of Second Language Pronunciation, 3, 109-135. https://doi.org/10.1075/jslp.3.1.05bur

Buss, L. (2016). Beliefs and practices of Brazilian EFL teachers regarding pronunciation. Language Teaching Research, 20, 619-637. https://doi.org/10.1177/1362168815574145

Celce-Murcia, M., Brinton, D., Goodwin, J., \& Griner, B. (2010). Teaching pronunciation: A reference for teachers of English to speakers of other languages (2nd ed.). Cambridge University Press.

Cook, V. (1999). Going beyond the native speaker in language teaching. TESOL Quarterly, 33, 185-209. https://doi.org/10.2307/3587717

Couper, G. (2016). Teacher cognition of pronunciation teaching amongst English language teachers in Uruguay. Journal of Second Language Pronunciation, 2, 29-55. https://doi.org/10.1075/ jslp.2.1.02cou

Couper, G. (2017). Teacher cognition of pronunciation teaching: Teachers' concerns and issues. TESOL Quarterly, 51, 820-843. https://doi.org/10.1002/tesq.354

Darcy, I. (2018). Powerful and effective pronunciation instruction: How can we achieve it? CATESOL Journal, 30, 13-45.

DeKeyser, R. (1998). Beyond focus on form: Cognitive perspectives on learning and practicing second language grammar. In C. Doughty \& J. Williams (Eds.), Focus on form in classroom language acquisition (pp. 42-63). New York: Cambridge University Press.

Deng, J., Holtby, A., Howden-Weaver, L., Nessim, L., Nicholas, B., Nickle, K., Pannekoek, C., Stephan, S., \& Sun, M. (2009). English pronunciation research: The neglected orphan of second language acquisition studies? (WP 05-09). Edmonton, AB: Prairie Metropolis Centre.

Derwing, T. M., \& Munro, M. J. (2015). Pronunciation fundamentals: Evidence-based perspectives for L2 teaching and research. Amsterdam: Benjamins.

Ellis, R., \& Shintani, N. (2014). Exploring language pedagogy through second language acquisition research. London: Routledge.

Foote, J., Holtby, A., \& Derwing, T. (2011). Survey of the teaching of pronunciation in adult ESL programs in Canada, 2010. TESL Canada Journal, 29, 1-22. https://doi.org/10.18806/tesl. v29i1.1086

Freeman, D., \& Johnson, K. E. (1998). Reconceptualizing the knowledge-base of language teacher education. TESOL Quarterly, 32, 397-417. https://doi.org/10.2307/3588114

Gass, S., \& Mackey, A. (2000). Stimulated recall methodology and second language research. Mahwah, $\mathrm{NJ}$ : Earlbaum.

Gatbonton, E. (2008). Looking beyond teachers' classroom behaviour: Novice and experienced ESL teachers' pedagogical knowledge. Language Teaching Research, 12, 161-182. https://doi. org $/ 10.1177 / 1362168807086286$

Gatbonton, E., \& Segalowitz, N. (2005). Rethinking communicative language teaching: A focus on access to fluency. Canadian Modern Language Review, 61, 325-353. https://doi.org/10.1353/ $\mathrm{cml} .2005 .0016$ 
Golombek, P., \& Jordan, S. (2005). Becoming "black lambs" not "parrots": A post-structuralist orientation to intelligibility and identity. TESOL Quarterly, 39, 513-533. https://doi. org $/ 10.2307 / 3588492$

Gorsuch, G., \& Beglar, D. (2004). Teaching second language acquisition courses: Views from new faculty. TESL-EJ, 8. https://doi.org/tesl-ej.org/ej29/a2.html

Graddol, D. (2006). English next: Why global English may mean the end of "English as a Foreign Language." London: The British Council.

Henderson, A., Curnick, L., Frost, D., Kautzsch, A., Kirkova-Naskova, A., Levey, D., Tergujeff, E., Waniek-Klimczak, E. (2015). The English pronunciation teaching in Europe survey: Factors inside and outside the classroom. In J. A. Mompean \& J. Fouz-Gonzáles (Eds.), Investigating English pronunciation: Trends and directions (pp. 260-291). London: Palgrave Macmillan.

Hill, H. C., Shilling, S. G., \& Ball, D. L. (2004). Developing measures of teachers' mathematics knowledge for teaching. Elementary School Journal, 105, 11-30.

Hismanoglu, M., \& Hismanoglu, S. (2010). Language teachers' preferences of pronunciation teaching techniques: Traditional or modern? Procedia: Social and Behavioural Sciences, 2, 983989. https://doi.org/10.1016/j.sbspro.2010.03.138

Holliday, A. (2010). Analyzing qualitative data. In B. Paltridge and A. Phakiti (Eds.), Continuum companion to research methods in applied linguistics (pp. 98-110). London: Continuum.

Jenkins, J. (2006). Current perspectives on teaching world Englishes and English as a lingua franca. TESOL Quarterly, 40, 157-181. https://doi.org/10.2307/40264515

Johnson, K. (1994). The emerging beliefs and instructional practices of preservice English as a second language teachers. Teaching and Teacher Education, 10, 439-452. https://psycnet.apa. org/doi/10.1016/0742-051X(94)90024-8

Johnson, K. (1999). Understanding language teaching: Reasoning in action. Boston: Heinle \& Heinle.

Johnston, B., \& Goettsch, K. (2000). In search of the knowledge base of language teaching: Explanations by experienced teachers. Canadian Modern Language Review, 56, 437-468. https://doi.org/10.3138/cmlr.56.3.437

Justi, R., \& Van Driel, J. (2005). A case study of the development of a beginning chemistry teacher's knowledge about models and modeling. Research in Science Education, 35, 197-219.

Kamhi-Stein, L. D. (2014). Non-native English-speaking teachers in the profession. In M. CelceMurcia, D. M. Brinton, \& M. Ann Snow (Eds.), Teaching English as a second or foreign language (4th ed.) (pp. 586-600). Boston: Heinle Cengage Learning.

Kachru, B. (1990). World Englishes and applied linguistics. World Englishes, 9, 3-20. https://doi. org/10.1111/j.1467-971X.1990.tb00683.x

Kennedy, S., \& Trofimovich, P. (2010). Language awareness and second language pronunciation: A classroom study. Language Awareness, 19, 171-185. https://doi.org/10.1080/0965841 6.2010 .486439

Kubanyiova, M., \& Feryok, A. (2015). Language teacher cognition in applied linguistics research: Revisiting the territory, redrawing the boundaries, reclaiming the relevance. Modern Language Journal, 99, 435-449. https://doi.org/10.1111/modl.12239

Lee, J., Jang, J., \& Plonsky, L. (2015). The effectiveness of second language pronunciation instruction: A meta-analysis. Applied Linguistics, 36, 345-366. https://doi.org/10.1093/applin/amu040

Lee, J., Murphy, J., \& Baker, A. (2015). "Teachers are not empty vessels": A reception study of Freeman and Johnson's (1998) reconceptualization of the knowledge base of second language teacher education. TESL Canada Journal, 33, 1-21. https://doi.org/10.18806/tesl.v33i1.1224

Levis, J. (2005). Changing contexts and shifting paradigms in pronunciation teaching. TESOL Quarterly, 39, 369-377. https://doi.org/10.2307/3588485

Levis, J., \& Grant, L. (2003). Integrating pronunciation into ESL/EFL classrooms. TESOL Journal, 12, 13-19. https://doi.org/10.1002/j.1949-3533.2003.tb00125.x

Levis, J., Sonsaat, S., Link, S., \& Barriuso, T. (2016). Native and nonnative teachers of L2 pronunciation: Effects on learner performance. TESOL Quarterly, 50, 894-931. https://doi.org/10.1002/ tesq. 272 
Macdonald, S. (2002). Pronunciation views and practices of reluctant teachers. Prospect, 17, 3-18. https://doi.org/hdl.handle.net/1959.14/323083

Mahboob, A. (2004). Native or nonnative: What do the students think? In L. D. Kamhi-Stein (Ed.), Learning and teaching experience: Perspectives on nonnative English-speaking professionals (pp. 121-147). Ann Arbor: University of Michigan Press.

Mahboob, A. (2010). The NNEST lens. In A. Mahboob (Ed.), The NNEST lens: Non native English speakers in TESOL (pp. 1-12). Newcastle upon Tyne, England: Cambridge Scholars.

McAlpine, L., Weston, C., Berthiaume, D., \& Fairbank-Roch, G. (2006). How do instructors explain their thinking when planning and teaching? Higher Education, 51, 125-155.

Medyes, P. (2017). The non-native teacher (3rd ed.). Scotland, UK: Swan Communication.

Merriam, S. B. (2009). Qualitative research: A guide to design and implementation. San Francisco: Wiley.

Miller, J. (2009). Teacher identity. In A. C. Burns \& J. C. Richards (Eds.), The Cambridge guide to second language teacher education (pp. 172-181). New York: Cambridge University Press.

Murphy, J. (2014a). Intelligible, comprehensible, non-native models in ESL/EFL pronunciation teaching. System, 42, 258-269. https://doi.org/10.1016/j.system.2013.12.007

Murphy, J. (2014b). Myth: ESL teachers are ready to teach pronunciation. In L. Grant (Ed.), Pronunciation myths. Ann Arbor: University of Michigan Press.

Murphy, J. (2017). Teaching the pronunciation of English: Focus on whole courses. Ann Arbor: University of Michigan Press.

Murphy, J. (2018). Teacher training in the teaching of pronunciation. In O. Kang, R. Thomson, \& J. Murphy (Eds.), The Routledge handbook of second language pronunciation (pp. 298-319). London: Routledge.

Nemtchinova, E. (2005). Host teachers' evaluations of nonnative-English-speaking teacher trainees: A perspective from the classroom. TESOL Quarterly, 39, 235-261. https://doi. org $/ 10.2307 / 3588310$

Patton, M. Q. (2002). Qualitative research and evaluation methods (3rd ed.). Thousand Oaks, CA: Sage.

Phillipson, R. (1992). Linguistic imperialism. Oxford: Oxford University Press.

Richards, K. (2003). Qualitative inquiry in TESOL. New York: Palgrave Macmillan.

Shulman, L. S. (1987). Knowledge and teaching: Foundations of the new reform. Harvard Educational Review, 57, 1-22. https://doi.org/10.2307/1175860

Sicola, L., \& Darcy, I. (2015). Integrating pronunciation into the language classroom. In M. Reed \& J. Levis (Eds.), The handbook of English pronunciation (pp. 471-486). West Sussex, England: Wiley Blackwell.

Sifakis, N., \& Sougari, A.-M. (2005). Pronunciation issues and EIL pedagogy in the periphery: A survey of Greek state school teachers' beliefs. TESOL Quarterly, 39, 467-488. https://doi. org $/ 10.2307 / 3588490$

Stake, R. E. (1995). The art of case study research. Thousand Oaks, CA: Sage.

Thomson, R., \& Derwing, T. M. (2015). The effectiveness of L2 pronunciation instruction: A narrative review. Applied Linguistics, 36, 326-344. doi:10.1093/applin/amu076

Timmis, I. (2002). Native-speaker norms and International English: A classroom view. ELT Journal, 56, 240-249. https://doi.org/10.1093/elt/56.3.240

Venkatagiri, H., \& Levis, J. (2007). Phonological awareness and speech comprehensibility: An exploratory study. Language Awareness, 16, 263-277. https://doi.org/10.2167/la417.0

Wyatt, M. (2009). Practical knowledge growth in communicative language teaching. TESL-EJ, 13, 1-23. http://www.tesl-ej.org/wordpress/issues/volume13/ej50/ej50a2/

Zielinski, B., \& Yates, L. (2014). Myth: Pronunciation instruction is not appropriate for beginninglevel learners. In L. Grant (Ed.), Pronunciation myths: Applying second language research to classroom teaching (pp. 56-79). Ann Arbor: The University of Michigan Press. 


\section{Appendices}

\section{Appendix A: The teacher writes the words "suit" and "sued" on the board to explain vowel length differences}

Student2: voiceless

Maria: voiceless (.) now [d] is it voiced or voiceless?

Students: voiced

Maria: ok (.) this vowel sound here is shorter (.) we just say [sut]

Students: [sut]

Maria: this one ([u::]) is longer because of the vibration of this sound (.) so we say $[\mathrm{su}:: \mathrm{d}]$

Students: $\quad[\mathrm{su}: \mathrm{d}]$

Maria: $\quad$ [su::d]

Students: $\quad[\mathrm{su}: \mathrm{d}]$

Maria: $\quad[\mathrm{su}:: \mathrm{d}]$ (.) you see the sound is a little bit longer (.) and that is one (.) um cause for lengthening the sound (.) the- - the vowel sound I mean (.) that depends on the consonant that is next to it (.) ok? (Class, Week 2)

\section{Appendix B: Example of Maria explaining intonation patterns:}

Maria:

now did you notice that some sentences have the arrow down, and others have the arrow up? [the teacher writes the sentences and draws arrows to demonstrate intonation patterns]

Student?: $\quad$ yes

Maria:

what is it for? Do you know? (4s) For example, number one says the object of the game is to win $\downarrow$ [teacher emphasizes falling intonation], and number three says, it looks hot, doesn't it? $\uparrow$ [the teacher emphasizes rising intonation]. It goes up because it's a tag question. It's clarifying, ok? And then number six says, what's your occupation? $\downarrow$ It's a question ok, a wh-question ok? So it goes down. Then um the intonation of sentences and questions is different. We're not going to go very deep in this because it is not part of this course, yet. But it's just for you to know that um, you have to either go up, or down depending on what you want to say, ok? Because if you say "that's his car $\downarrow$ " you are affirming that that is his car $(2 \mathrm{~s})$, but if you say "that's his car个" you're asking, ok? So, you have to- we need to be very careful with these intonation patterns. By now it's just for you to get a little bit familiar with it, ok? Now, there on the same page ... (Class, Week 7)

\section{Appendix C: Maria explains her rationale for using arrows, stress marks, and phonetic symbols on the board:}

Well this was just to clarify, and to try to explain it in an easier way I guess. As I said, some students just get it by seeing, I mean they don't even need to see the sentence on the board, but some others really need it, and some others really need to see 
those arrows and those things [stress marks]. So I guess that the experience gives you this, just makes you work in a holistic way let's say, just for everybody to understand. (Maria, Interview 3)

\section{Appendix D: Maria explains the importance of making students aware of different phonetic aspects:}

Just to be able to know how to produce sounds and why. Because I remember when we were studying the $-\mathrm{s}$ endings, or the -ed ending pronunciation, for them at the beginning it was difficult to see the difference between the three sounds. Then after the explanation, after saying "ok this is [d] because of this and this and this ..." so now I've noticed that every time they pronounce something and they use an -s ending or an -ed ending, they're like aware of what they're doing, and sometimes they even stop before saying the word maybe just to try to remember the rule. I don't know, but at least they are aware of the situation, so I think that it is important for them to have that basis in order to be able to speak correctly. (Maria, Interview 2)

\section{Appendix E: Maria explains the importance of having students work in groups:}

Sometimes it's easier to notice the other people's mistakes than our own mistakes. If I'm speaking I'm thinking that I'm saying everything correct. So if another person is checking me it's easier because -I always just tell them "you listen to the person and you just mark the words or the things that that person said incorrectly" so that you can tell the other person at the end, "these and these and these words were the ones you mispronounced" just for them to get feedback and then practice the words or just repeat the words. Because it's easier, or it's better to have another person to check my mistakes than me myself checking my own mistakes. (Maria, Interview 3)

\section{Appendix F: Example of students helping each other while reading a dialogue:}

Student1:

Student2:

Student1:

Student2:

Student1:

Student2:

Student1:

Student2:

Student1: hi Justine, how's my (?) loving cousin?

very worried, I just had a (?) a tough [tov]

tough! [t $\Lambda \mathrm{f}]$

tough $[\mathrm{t} \Lambda \mathrm{f}]$ ? tough $[\mathrm{t} \Lambda \mathrm{f}]$ luck

why? what's up?

my bus got ... stuck ... in the mud, and I just lost some money. I should carry something for luck... I should

yes, here's some other advice, never walk [wolk] . . walk [wok] under ladders, and run (2s) from [fion]?

from! [f.əom]

from [f.ım], black cats, they are nothing but trouble. (Class, Week 9) 


\section{Appendix G: Maria introduces the vowel sound schwa in class:}

Maria: [the teacher writes on the board] ok this sound is called - do you know how it's called? It's called "the schwa." That's the name of the symbol, but this sound is one of the most frequent sounds in English, but it's one that we don't have in Spanish. So for us Spanish speakers it is kind of difficult to produce it sometimes, ok? For example when we say "but" we tend to say [bat] or [bot], ok? But it's [bot], it's a very relaxed sound. It's just -you just leave your mouth like . . . free, and say [bət]. That's the sound, it's not [a] it's not [ $\varepsilon$ ] it's not [i] it's [ə]. (Class, Week 4) 